\title{
Konferencja naukowa „Filozofia wychowania Sergiusza Hessena”
}

Konferencja odbyła się w Warszawie 27.II.1996 roku. Jej organizatorem bylo Polskie Towarzystwo Pedagogiczne (Oddział Warszawski) oraz Wydział Pedagogiczny Uniwersytetu Warszawskiego. Sesja miała charakter jednodniowego plenarnego spotkania uczonych $\mathrm{z}$ większości osrodków akademickich w Polsce.

W konferencji wzięli udział znani, wybitni uczeni, a wśród nich także uczniowie i przyjaciele S. Hessena oraz mniej liczne grono młodych pracowników nauki. Wystąpienia można podzielić na kilka grup: opracowania bio- i biodoksograficzne oraz wystapienia nawiqzujące do Hessenowskiej pedagogiki kultury lecz odchodzące od interpretacji oryginalnych tekstów tego filozola wychowanis.

Na sesji wystąpili: W. Okoń - S. Hessen w swietle autobiografii; T. Nowacki - U podstaw twórczości S. Hessena; I. Wojnar - Koncepcja ksztalcenia ogólnego w myśli S. Hessena; A. Folkierska - S. Hessen pedagog odpowiedzialny; S. Woloszyn - S. Hessen wobec wychowania swobodnego J. J. Rousseau i L. Tolstoja; A. Pluta - Filozoficzno-kulturowy kontekst dydaktyki krytycznej S. Hessena inspiracjq dla pedagogiki pogranicza; S. Sztobryn - Transcendentalny empiryzm jako postac Hessenowskiego neokantyzmu; M. Cichosz - Próba przelamania scjentystycznego modelu uprawiania pedagogiki na przykladzie S. Hessena; J. Półturzycki - Poglady Hessena na pedagagikp doroslych; E. Kukuła - Platoniska teoria cnót - na marginesie tekstu Hessena "Cnoty starożytne a cnoty ewangeliczne"; J. Lipiec - Filozoficzne podstawy edukacji - na marginesie pedagogiki Hessenowskiej.

Całosć obrad zamknęła krótka dyskusja. Planowane jest wydawanie tekstów wystąpień.

Slawomir Sztobryn

\section{Zapowiedzi}

\section{International Standing Conference for the History of Education. ISCHE XVIII w Krakowie}

W dniach 6-9 VIII 1996 r. odbędzie się w Krakowie Międzynarodowa Konferencja Historyków Wychowania - ISCHE XVIII. Glównym organizatorem jest Katedra Historii Oświaty i Wychowania Wyższej Szkoły Pedagogicznej w Krakowie. Tematem konferencji jest Szkolnictwo w zmieniajacych się spoleczensstwach. Perspektywa historyczna $i$ porównawcza (1750-1996). W programie konferencji przewidziane sq wykłady pelname, obrady w pięciu sekcjach tematycznych oraz dyskusje okragkego stołu. Tematyka obrad sekcyjnych obejmuje:

1. Przemiany ekonomiczno-społeczne a ewolucja wychowania;

2. Edukacyjne konsekwencje przemian politycznych;

3. Dzieje reform edukacyjnych. Przemiany edukacyjne w świetle legislacji;

4. Wpływ teorii edukacyjnych na przemiany w dziedzinie oświaty i wychowaniu;

5. Teoretyczne problemy historiografii i metodologii badań dziejów oświaty i wychowania.

Obrady odbywać się będą w głównym gmachu WSP w Krakowie ul. Podchorążych 2.

Kontakt $\mathrm{z}$ organizatorem konferencji za pośrednictwem:

tel. 12374777 , wew. 515

tel/[ax: 12379513

fax: 12372243

e-mail: spmajore kinga. @ cyf-kr. edu. pl 
Poniżej podaję skrócone wersje dwóch cyrkularzy ISCHE XVIII. Znajdują się w nich podstawowe informacje o konferencji. Ponieważ głównym językiem ISCHE jest angielski, informacje te przekazuje w tym wlaśnie języku. W imieniu Komitetu Organizacyjnego zapraszam wszystkich polskich historyków wychowania do wzięcia udziału w tej unikalnej w skali światowej imprezie historyczno-edukacyjnej. Dotychczas (16 luty 1996) awizuja w niej udzial najwybitniejsze postacie światowej historii wychowania.

Madyslawa Szulakiewicz

ISCHE XVIII Kraków

August 6-9, 1996

\section{Schooling in changing societies historical and comparative perspectives (c. 1750-1996)}

In modern times, certainly since the rise of the modern nation state and perhaps even earlier, civil authorities, whether local, regional or national, became increasingly interested in organizing and controlling education from the early grades through the university. At the same time, many educators subscribed to educational theories and educational practices that disregarded all boundaries, regional, national, political, racial, ethnic and gender. As modern societies became increasingly competitive with each other as well as increasingly interdependent and moved toward the creation of the global society, education was increasingly conceived of as an instrument for achieving society's social, political and economic agenda. Consequently, officials in the political sector often assumed responsibility for organizing and reforming education - for introducing new forms of schooling, new school subjects, new curricula, new methods for teaching and specified methods for evaluating both students and their teachers.

The historian of education now has the opportunity and the responsibility to investigate the nature of the relationship between education and the many changes in the social, economic, political and legal structures, especially those changes that have occured since the time of the Enlightenment, c. 1750 . Consideration of this relationship suggests many questions: Has education been the means whereby the social, political, economic and legal structures have been changed? $\mathrm{Or}$, are the various forms of education known to the historian the results of social, political, economic and legal structures? What are the relationships among classical, modern and post-modern educational theories and educational philosophies? Is the history of educational theories and educational philosophies? Is the history of educational reform instructive? How have the aims and purposes of education, pedagogical methods, curriculum, organization and administration of education been affected by deliberate attempts at educational reform? How have they been affected by changes in the social, political, economic and legal structures of society?

The conference will include plenary sessions for invited speakers, parallel paper sessions and round table discussions. The main language of the conference is English, but papers in the other ISCHE languages - French, German and Spanish - are welcome.

\section{Plenary Lectures}

Leading historians of education from Europe, North America, Africa and Australia have confirmed their readiness to deliver lectures at the ISCHE XVIII. They will discuss key issues on Schooling in Changing Societies or even on the History of Education within an international scope. We have already received proposals from several invited speakers who are going to present very interesting topics, for example: 